\title{
Study of Growth Rate in Nile Tilapia (Oreochromis niloticus)
}

\section{Mounika Nakkina*}

Department of Information Technology, Jawaharlal Nehru Technological University, Kakinada, India

*Corresponding author: Mounika Nakkina, Department of Information Technology, Jawaharlal Nehru Technological University, Kakinada, India, Tel: 9032436691; Email: mounika.inom@gmail.com

Rec date: July 27, 2016; Acc date: August 18, 2016; Pub date: August 20, 2016

Copyright: ( 2016 Nakkina M. This is an open-access article distributed under the terms of the Creative Commons Attribution License, which permits unrestricted use, distribution, and reproduction in any medium, provided the original author and source are credited.

\begin{abstract}
This study shows the effect of wastewater of El-Sail Drain on the strength of Oreochromis niloticus gathered from two destinations of River Nile at Aswan Governorate. The physicochemical parameters of water such as $\mathrm{pH}$, electric conductivity, complete broke down solids, disintegrated oxygen, organic and concoction oxygen requests; nitrite, nitrate and alkali were resolved. Substantial metals $(\mathrm{Cu}, \mathrm{Pb}, \mathrm{Cd}$ and $\mathrm{Ni}$ ) fixations in water and fish tissues were recognized. The microbiological, parasitological and neurotic states of fish were likewise researched. Higher estimations of $\mathrm{pH}, \mathrm{EC}, \mathrm{BOD}$ and $\mathrm{COD}$ were recognized in site II than from site I. As opposed to DO, nitrite, nitrate and smelling salts which were lower in site II. Substantial metals focuses in water of both sites, particularly $\mathrm{Ni}, \mathrm{Pb}$ and $\mathrm{Cd}$ surpassed as far as possible and its abundance followed the order: $\mathrm{Pb}>\mathrm{Ni}>\mathrm{Cd}>\mathrm{Cu}$. Total bacterial count, all out coliform, Salmonella sp., Shigella sp. and E. coli were recognized in higher numbers in water tests from site II. Additionally, the fish got from that site revealed higher bacterial and parasitic contamination. The bioaccumulation of $\mathrm{Ni}$ and $\mathrm{Pb}$ surpassed the most extreme allowable limit; in any case, $\mathrm{Cu}$ and $\mathrm{Cd}$ focuses were underneath as far as possible in various tissues. The bioaccumulation variable of $\mathrm{Cu}$ demonstrated its most noteworthy worth in liver. The histopathological injuries were more prominent in fish gathered from site II. Thus, expending fish got from the considered locales around El-sail drain disposal point speaks to serious risk on human health.
\end{abstract} Keywords: Oreochromis niloticus; Parasitic infection;
Histopathological lesions

\section{Introduction}

Nile tilapia, Oreochromis niloticus (O. niloticus) is considered as a standout amongst the most critical freshwater species for commercial aquaculture because of its high nutritional qualities, quick development rate and resistance to illnesses [1,2]. However, bacterial ailments episode keeps on happening among refined O. niloticus because of high strengthening, bringing on impressive monetary misfortunes in fish ranches [3-6]. A few methodologies, for example, inoculation and chemotherapy have been done to build fish immunocompetence and prevent aquatic diseases (Figure 1).

With the expansion in escalated aquaculture, interest for more proficient aqua-feed is rising. Sustain involves the principle operating cost in fish generation and the principle protein source has generally been fish feast [7-9]. Fishmeal, the traditional protein source in aquaculture sustains, supports good fish development in light of its protein quality and tastefulness $[10,11]$.

In any case, fish supper is regularly rare and costly, because of restricted accessibility and appeal, which frequently prompts high fish generation costs [12-17]. Supplanting fish supper with less expensive elements of either creature beginning or protein-rich plant sources is an essential need for sustenance research. In perspective of this, oilseed suppers have been found to have impressive financial potential [18-21]. While grain vegetables have not been broadly utilized inside aquaculture feeds, oilseeds and their repercussions habitually constitute a noteworthy wellspring of dietary protein inside aquaculture nourishes for warm water fish species [22-25].

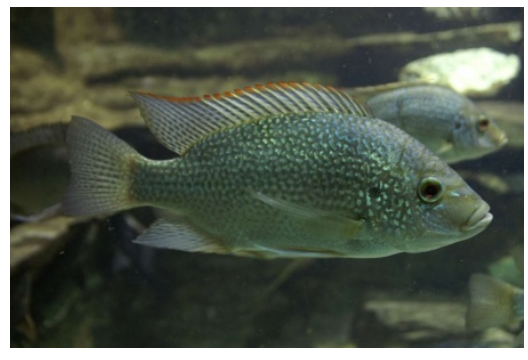

Figure 1: Nile Tilapia Oreochromis niloticus (O. niloticus).

The cost of fish food covers from $50 \%$ to $60 \%$ of the aggregate operation expense of aquaculture generation. The capable component for the addition of fish food generation and its cost is the fast development rate of aquaculture industry [26-31]. The restricted source of feed ingredients, for example, fish feast, fish oil and soybean meal are additionally the primary motivation to build the cost of aquafeed. Besides, an expanding of human interest for supplements got from those ingredients could lessen the commitment of those ingredients towards fulfilling the interest for reasonable aqua-feed production [32-35]. In this way, there is no serious concern on the long term accessibility of these food elements for use in aqua-feed production [36,37].

The need to recognize elective wellspring of protein to grow minimal effort encourage feed ingredients on the basis of reasonable and renewable food assets for small and medium scale fish ranchers are along these lines, essential [38-41]. It is additionally imperative to consider that the chose encourage ingredients don't struggle with human sustenance security interests. 


\section{Collection and Formulation of Feed Ingredients}

Chosen potential food ingredients with a unique spotlight on wellsprings of plant root were utilized as a part of this study [42-47]. Choice of the feedstuffs depended on the accessibility of the ingredients. The agro-industrial by-products accessible in Hawassa city, for example, wheat grain, beer waste; potato scrap and Jatropha seed cake meal were gathered from various production lines [48-51]. Cereals, for example, maize, sorghum, wheat, rice, soybean, bone supper and groundnut were bought from local markets. Later, six exploratory eating regimens containing $40 \%$ of 1 Maiz:1Sorghum for control diet or diet "A", coffee husk/pulp for diet "B", wheat bran for diet "C", beer sludge for diet " $D$ ", potato scrap for diet "E" and 2JCKM:1, Wheat: 1, Rice for diet " $F$ " were planned by blending with basal food ingredients like soy bean, bone/meat dinner and groundnut $[52,53]$. In the wake of blending, all the food ingredients were sun-dried and pounded into powder utilizing an electric sledge factory. The final mixture of every diet was made into moist pellets and after that sundried and after that squashed into smaller size (range from 1-2 mm size) and put into plastic packs [54-57] (Figure 2).

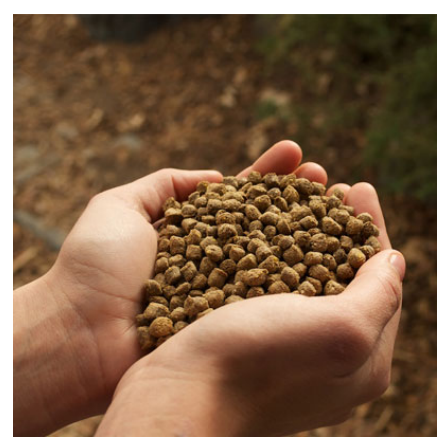

Figure 2: Raw materials for production of fish feed.

\section{Medical Advantages of Tilapia}

Eating of Nile Tilapia fish benefits human in many ways by preventing Heart Diseases because of high-quality proteins, omega-3 fatty acids and amino acids [58-60]. Eating tilapia all the time may help you control your body weight. Utilization of these sorts of unsaturated fats is thought to be connected with decrease in circulatory strain and lessened danger for specific diseases, provocative conditions, for example, rheumatoid joint inflammation, and even mental decay [61-67]. Tilapia is actually low in fat, and just contains around 128 calories in each 3.5-ounce bit. Tilapia also helps people to manage the blood sugar-levels.

\section{Is Tilapia Dangerous to Human Health?}

Individuals who eat more fish has brought about utilization of expanding amounts of fish, for example, tilapia that may accomplish more harm than good, since they contain elevated amounts of omega- 6 unsaturated fats, likewise called n-6 PUFAs, for example, arachidonic corrosive [68-70]. Tilapia may contain mercury and different contaminants that could be unsafe for pregnant ladies, nursing ladies and young children.

\section{Discussion}

The development and food use effectiveness of adolescent $\mathrm{O}$. niloticus were influenced by various natural components, for example, water quality parameters including water temperature, $\mathrm{pH}$, nitrogen waste, dissolved oxygen fixation, and food quantity and quality, hereditary cosmetics, sex of the fish and their collaboration [71]. Generally, the protein nature of dietary ingredients is one of the main elements influencing fish execution and protein absorbability is the principal measure of its accessibility to Fish. Protein nature of dietary protein sources relies on upon the amino acid structure and their absorbability [72,73]. The absorbability of ingredients gives knowledge concerning supplement usage and ought to empower better ingredient substitutions in weight control plans intended for target species. The supplement absorbability will differ based upon the arrangement of ingredients utilized.

\section{References}

1. Mapenzi LL, Mmochi AJ (2016) Role of salinity on growth performance of Oreochromis niloticuso 9 and Oreochromis urolepis urolepis ${ }^{\top}$ Hybrids. J Aquac Res Development 7: 431.

2. Abd EEA, Abd EAM, Shourbela RM (2016) Enhancement of antioxidant activity, non-specific immunity and growth performance of nile tilapia, Oreochromis niloticus by dietary fructooligosaccharide. J Aquac Res Development 7: 427.

3. Manaf SR, Daud HM, Alimon AR, Mustapha NM, Hamdan RH, et al. (2016) The Effects of Vitex trifolia, Strobilanthes crispus and Aloe vera Herbal-mixed Dietary Supplementation on Growth Performance and Disease Resistance in Red Hybrid Tilapia (Oreochromis sp.). J Aquac Res Development 7: 425.

4. Hassaan MS, Soltan MA (2016) Evaluation of essential oil of fennel and garlic separately or combined with Bacillus licheniformis on the growth, feeding behaviour, hemato-biochemical indices of Oreochromis niloticus (L.) Fry. J AquacRes Development 7: 422.

5. Ali HA, Ali JA, Musthafa SM, Kumar MSA, Naveed SM, et al. (2016) Impact of formulated diets on the growth and survival of ornamental fish Pterophyllum Scalare (Angel Fish). J Aquac Res Development 7: 421.

6. Moosavi MJ, Shamushaki VAJ (2015) Effects of different levels of copper sulfate on growth and reproductive performances in guppy (P. reticulate). J Aquac Res Development 6: 305.

7. Sanz A, Furné M, Hidalgo MC, Domezain A, García-Gallego M (2015) Growth and digestive enzymatic profile of Acipenser naccarii and Oncorhynchus mykiss Fed on Different Dietary Macronutrient Levels. A Comparative Study. J Aquac Res Development 6: 300.

8. Workagegn KB, Ababboa ED, Yimer GT, Amare TA (2014) Growth performance of the nile tilapia (Oreochromis niloticus L.) Fed different types of diets formulated from varieties of feed ingredients. J Aquac Res Development 5: 235.

9. Roncarati A, Mordenti O, Stocchi L, Melotti P (2014) Comparison of growth performance of 'common catfish Ameiurus melas, Rafinesque 1820 , reared in pond and in recirculating aquaculture system. J Aquac Res Development 5: 218.

10. Workagegn KB, Ababbo ED, Tossa BT (2013) The effect of dietary inclusion of Jatropha curcas kernel meal on growth performance, feed utilization efficiency and survival rate of juvenile nile tilapia. J Aquac Res Development 4: 193.

11. Kalantarian SH, Rafiee GH, Farhangi M, Mojazi AB (2013) Effect of different levels of dietary calcium and potassium on growth indices, biochemical composition and some whole body minerals in rainbow trout (Oncorhynchus mykiss) Fingerlings. J Aquac Res Development 4: 170 .

12. Nekoubin H, Sudagar M (2013) Effect of different types of plants (Lemna Sp., Azolla filiculoides and Alfalfa) and artificial diet (with two protein levels) on growth performance, survival rate, biochemical parameters and 
body composition of grass carp (Ctenopharyngodon idella). J Aquac Res Development 4: 167.

13. Ozovehe BN (2013) Growth performance, haematological indices and some biochemical enzymes of juveniles Clarias gariepinus (Burchell 1822) Fed Varying Levels of Moringa oleifera Leaf Meal Diet. J Aquac Res Development 4: 166.

14. Kefi AS, Kangombe J, Kassam D, Katongo C (2012) Growth, reproduction and sex ratios in Oreochromis Andersonii (Castelnau, 1861) Fed with Varying Levels of 17a-Methyl Testosterone. J Aquacult Res Dev 3: 155.

15. Adloo MN, Matinfar A, Sourinezhad I (2012) Effects of feeding enriched Artemia fransiscana with HUFA, Vitamin C and E on growth performance, survival and stress resistance of yellowfin seabream larvae. J Aquacult Res Dev 3: 157.

16. Singh SK, Mishra U, Roy SD, Chadha NK, Venkateshwarlu G (2012) Effect of feeding enriched formulated diet and live feed on growth, survival and fatty acid profile of deccan mahseer, Tor Khudree (Sykes) First Feeding Fry. J Aquacult Res Dev 3: 143.

17. Yadav AK, Srivastava PP, Shrivastava P, Chowdhary S, Dayal R, et al. (2012) A growth responses of animal and plant origin dietary lipids on the survival, growth and feed efficiency of asian catfish, Clarias batrachus (Linnaeus, 1758) Grow-out. J Aquacult Res Dev 3: 138.

18. Chowdhary S, Srivastava PP, Mishra S, Dayal R, Yadav AK, et al. (2012) Evaluation of partial replacement of dietary animal protein from plant protein blended with glucosamine on growth and body indices of asian catfish (Clarias Batrachus) Fingerlings. J Aquac Res Development 3: 129.

19. Shelar GS, Dhaker HD, Pathan DI, Shirdhankar MM (2012) Effect of different organic manures on the growth of screw Vallisneria, Vallisneria spiralis Linne 1753. J Aquac Res Development 3: 121.

20. Huynh HPV, Nugegoda D (2011) Effects of dietary supplements on growth performance and phosphorus waste production of australian catfish, Tandanus tandanus, fed with diets containing canola meal as fishmeal replacement. J Aquac Res Development 2: 117.

21. Strand A, Magnhagen C, Alanärä A (2011) Growth and energy expenditures of eurasian perch Perca fluviatilis (Linnaeus) in different temperatures and of different body sizes. J Aquac Res Development 2: 114.

22. Tewary A, Patra BC (2011) Oral administration of baker's yeast (Saccharomyces cerevisiae) acts as a growth promoter and immunomodulator in Labeo rohita (Ham.). J Aquac Res Development 2: 109.

23. Elgendy MY, Abdelsalam M, Moustafa M, Kenawy AM, Seida A (2015) Caligus elongatus and Photobacterium damselae subsp piscicida Concomitant infections affecting broodstock European seabass, Dicentrarchus Labrax, with Special Reference to histopathological responses. J Aquac Res Development 6: 346.

24. Grasteau A, Guiraud T, Daniel P, Calvez S, Chesneau V, et al. (2015) Evaluation of Glutaraldehyde, Chloramine-T, Bronopol, Incimaxx Aquatic $^{\bullet}$ and Hydrogen Peroxide as Biocides against Flavobacterium psychrophilum for Sanitization of Rainbow Trout Eyed Eggs. J Aquac Res Development 6: 382 .

25. Sarkar UK, Sharma J, Mahapatra BK (2015) A review on the fish communities in the indian reservoirs and enhancement of fisheries and aquatic environment. J Aquac Res Development 6: 297.

26. Awaiss A (1991) Mass culture and nutritional quality of the freshwater rotifer (Brachionus calyciflorusP.) for gudgeon (Gobio gobio L.) and perch (Perca fluviatilisL.) larvae. Spec eur Aquacult Soc 15: 113-115.

27. James R, Sampath K (2003) Effect of meal frequency on growth and reproduction in the ornamental red swordtail, Xiphophorus helleri. Israeli Journal of Aquaculture-Bamidgeh 55: 197-207.

28. Schnaittacher G, King W, Berlinsky DL (2005) The effects of feeding frequency on growth of juvenile Atlantic halibut, Hippoglossus hippoglossus L. Aquacult Res 36: 370-377.

29. Carani FR, Da Silva DBO, Piedade WP, Da Costa FAA, De Almeida-Val VMF, et al. (2014) Expression of growth-related factors in skeletal muscle of pirarucu (Arapaima Gigas) during Growth. J Aquac Res Development 5: 272 .

30. Quaiyum MA, Jahan R, Jahan N, Akhter T, Sadiqul IM (2014) Effects of bamboo charcoal added feed on reduction of ammonia and growth of Pangasius hypophthalmus. J Aquac Res Development 5: 269.

31. Moza U, De Silva SS, Mitchell BM (1995) Effect of sub-lethal concentrations of cadmium on food intake, growth and digestibility in the goldfish, Carassius auratus L. J Environ Biol 16: 253-64.

32. Li MH, Manning BB, Oberle DE, Robinson EH (2005) Effects of maintenance feeding regimens on weight gain, feed efficiency, and body condition of pond-raised channel catfish. North American Journal of Aquaculture 67: 129-132.

33. patrick si, naamani s, ghanawi j, nasser $\mathrm{n}$ (2014) effects of acute and chronic nitrite exposure on rabbitfish Siganus rivulatus growth, hematological parameters, and gill histology. J Aquac Res Development 5: 263.

34. Qamer M, Asad F, Tahir N (2014) Changes in body growth of Labeo rohita in relation to dietary carbohydrate content and protein levels using gelatinized and non-gelatinized corn. J Aquac Res Development 5: 248.

35. Lin YP, Chung WJ, Wu JL, Hu SY (2014) The liver-enriched transcription factors HNF-1 $\alpha, H N F-3 \beta$, and C/EBP $\beta$ contribute to the growth hormone-induced transcription of the progranulin a gene in Zebrafish (Danio Rerio). J Aquac Res Development 5: 237.

36. Abdelhamid E, Mohamed KA (2008) Effect of using probiotics as growth promoters in commercial diets for monosex Nile tilapia (Oreochromis niloticus) fingerlings. Proceedings of the Eighth International Smposium on Tilapia in Aquaculture, 12-14 October 2008, Cairo, Egypt.

37. Adewolu MA, Akintola SL, Akinwunmi OO (2009) Growth performance and survival of hybrid African catfish larvae (Clarias gariepinus $\mathrm{X}$ Heterobranchus bidorsalis) fed different diets. Zoologists 7: 45-51.

38. Cho SH, Lee S (2012) Onion powder in the diet of the olive flounder, Paralichthys olivaceus. Effects on the growth, body composition, and lysozyme activity. J World Aquac Soc 43: 30-38.

39. Mzengereza K, Kangombe J (2016) Effect of dietary salt (sodium chloride) supplementation on growth, survival and feed utilization of Oreochromis shiranus (Trewavas, 1941). J Aquac Res Development 6: 388.

40. Moniruzzaman M, Uddin KB, Basak S, Mahmud Y, Zaher M, et al. (2015) Effects of stocking density on growth, body composition, yield and economic returns of monosex tilapia (Oreochromis niloticus L.) under cage culture system in Kaptai Lake of Bangladesh. J Aquac Res Development 6: 357.

41. Adam B, Zofia S (2015) Subchronic effects of ectoine on survival, growth and physiological parameters of Daphnia Magna. J Aquac Res Development 6: 352.

42. El-Drawany MA, Elnagar WG (2015) Growth, food and feeding habits of Bagrus bayad and Bagrus docmac inhibiting muess channel, Sharkia Province, Egypt. J Aquac Res Development 6: 348.

43. Hafeez-ur-Rehman M, Iqbal KJ, Abbas F, Mushtaq MMH, Rasool F, et al. (2015) Influence of feeding frequency on growth performance and Body Indices of Goldfish (Carrassius auratus). J Aquac Res Development 6: 336.

44. Dada AA (2015) Improvement of tilapia (Oreochromis niloticus Linnaeus, 1758) Growth performance fed three commercial feed additives in diets. J Aquac Res Development 6: 325 .

45. Dada AA (2012) Effects of herbal growth promoter feed additive in fish meal on the performance of nile tilapia (Oreochromis niloticus L.). Egypt Acad J Biolog Sci 4: 111-117.

46. Dada AA, Oviawe NE (2011) The use of bitter kola Garcinia kola dry seed powder as a natural growth- promoting agent for African sharptooth catfish Clarias gariepinus fingerlings. Afr J Aquat Sci 36: 97-100.

47. Deng J, An Q, Bi B, Wang Q, Kong BL, et al. (2011) Effect of ethanolic extract of proplis on growth performance and plasma biochemical parameters of rainbow trout (Oncorhynchus mykiss). Fish Physiol Biochem 37: 959-967. 
Citation: Nakkina M (2016) Study of Growth Rate in Nile Tilapia (Oreochromis niloticus). J Aquac Res Development 7: 440. doi:

48. Davidson JW, Kenney PB, Manor M, Good CM, Weber GM, et al. (2014) Growth performance, fillet quality, and reproductive maturity of rainbow trout (Oncorhynchus mykiss) cultured to 5 kilograms within freshwater recirculating systems. J Aquac Res Development 5: 238.

49. Ronald N, Gladys B, Gasper E (2014) The effects of stocking density on the growth and survival of nile tilapia (Oreochromis niloticus) Fry at Son Fish Farm, Uganda. J Aquac Res Development 5: 222.

50. Diab AS, El-Nagar OG, Abd-El-Hady MY (2002) Evaluation of Nigella sativa L. (black seeds, Baraka), Allium sativum (garlic) and biogen as feed additives on growth performance and immunostimulants of Oreochromis niloticus fingerlings. Suez Canal Vet Med J 2: 745-753.

51. EL-Haroun ER (2007) Improved growth rate and feed utilization in farmed African catfish Clarias gariepinus (Burchell 1822) through a growth promoter Biogen ${ }^{\oplus}$ supplementation. J Fish Aquat Sci 2: 319-327.

52. Rama NP, Elezabeth MA, Uthayasiva M, Arularasan S (2014) Seaweed Ulva reticulata a potential feed supplement for growth, colouration and disease resistance in fresh water ornamental gold fish, Carassius auratus. J Aquac Res Development 5: 254.

53. EL-Haroun ER, Ma A, Goda S, Kabir CMA (2006) Effect of dietary probiotic Biogens supplementation as growth promoter on growth performance and feed utilization of Nile tilapia, Oreochromis niloticus (L.). Aquac Res 37: 1473-1480.

54. Felicitta J, Arti MR, Ronald J, Sakthika T, Nagarajan R, et al. (2013) Effect of different concentrations of some phytoadditives (Allium sativa and Allium cepa) on growth, survival and hematological parameters in tilapia (Oreochromis mossambicus) juveniles. The Israeli Journal of Aquaculture- Bamidgeh 64: 8 .

55. Khattab YAE, Shalaby AME, Sharaf SM, El-Marakby H, RiziAlla EH (2004) The physiological changes and growth performance of the nile tilapia Oreochromis niloticus after feeding with Biogen ${ }^{\star}$ as growth promoter. Egypt J Aquat Biol Fish 8: 145-158.

56. Kusuma HS, Putra AFP, Mahfud M (2016) Comparison of two isolation methods for essential oils from orange peel (Citrus auranticum $\mathrm{L}$ ) as a growth promoter for fish: Microwave steam distillation and conventional steam distillation. J Aquac Res Development 7: 409.

57. Yones AMM, Metwalli AA (2016) Effects of fish meal substitution with poultry by-product meal on growth performance, Nutrients utilization and blood contents of juvenile nile tilapia (Oreochromis niloticus). J Aquac Res Development 7: 389.

58. Turan F, Akyurt I (2005) Effects of red clover extract on growth performance and body composition of African catfish Clarias gariepinus (Burchell, 1822). Fish Sci 71: 618-620.

59. Fauconneau B, Paboeuf G (2001) Muscle satellite cells in fish. Fish Physiology 18, Muscle growth and development, London, UK.

60. Alam MS, Teshima S, Ishikawa M, Koshio S (2002) Arginine requirement of juvenile Japanese flounder Paralichthys olivaceus. Estimated by growth and biochemical parameters. Aquacult 205: 127-140.
61. Srivastava P, Singh A (2013) Study of in-vivo effects caused by metabolites (1,2,4-Trizole Alanine) of steroid-inhibitor fungicide on aquatic life (Fish). J Aquac Res Development 4: 183.

62. Bag MP, Mahapatra SC, Rao PS (2012) Aquatic weed as potential feed for mozambique tilapia, Oreochromis mossambicus. J Aquacult Res Dev 3 : 154.

63. Sung YY, MacRae TH (2011) Heat shock proteins and disease control in aquatic organisms. J Aquac Res Development S2: 006.

64. Bekele J, Hussien D (2015) Prevalence of internal parasites of Oreochromis niloticus and Clarias gariepinus fish species in lake Ziway, Ethiopia. J Aquac Res Development 6: 308.

65. Dubey SK, Trivedi RK, Rout SK, Chand BK, Choudhury A (2014) Median Lethal Salinity (MLS96 h) of two small indigenous fish species Amblypharyngodon mola and Pethia ticto from Indian Sundarban. J Aquac Res Development 5: 249.

66. Moe T, Ishikawa M, Koshio S, Yokoyama S (2009) Effects of dietary bamboo charcoal on growth parameters and nutrient utilization of tiger puffer fish, Takifugu rubripes. Aquacult Sci 57: 53-60.

67. Moe T, Koshio S, Ishikawa M, Yokoyama S (2010) Effects of supplementation of dietary bamboo charcoal on growth performance and body composition of juvenile Japanese flounder, Paralichthys olivaceus. J World Aquacult Soc 41: 255-262.

68. Al JS, Machkevskyi V, Al SS, Faraj RB, Al MN (2014) Biological and ecological features of Poecilancistrum Sp. Plerocercoid (Cestoda: Trypanorhyncha) infection of Arabian Sea Meager Argyrosomus heinii (Steindachner, 1907). J Aquac Res Development 5: 227.

69. Mary LR, Kurcheti PP, Babu G, Purushothaman CS (2013) Effect of Aeromonas hydrophila infection on caspase-3 expression and activity in rohu, Labeo rohita. J Aquac Res Development 4: 200.

70. Paulraj A, Lima-Filho JV, Altaff K, Peixoto S (2012) Atypical chytridiomyces fungal infection in cultured Macrobrachium rosenbergii in India. J Aquac Res Development 3: 122.

71. Beamish R, Gordon E, Wade J, Pennell B, Neville C, et al. (2011) The winter infection of sea lice on salmon in farms in a coastal inlet in British Columbia and possible causes. J Aquac Res Development 2: 107.

72. Alam MS (2004) Growth performances and morphological variations among Thai pangas, $P$. hypophthalmus collected from four different hatcheries in Mymensingh. Bang J Prog Agr 15: 141-149.

73. Azimuddin KM (1998) Effect on stocking density on the growth of Thai pangus, Pangasius sutchi (Folwer) in net cage by using formulated diet, MS Thesis, Department of Aquaculture, Bangladesh Agricultural University, Mymensingh, Bangladesh. 